\title{
Bazı ekmeklik buğday yalın çeşit ve tarla paçallarının tarımsal özellikler, kalite ve karlılık bakımından incelenmesi
}

\section{An assessment on some bread wheat pure varietes and field mixtures}

\author{
Irfan ÖZBERK ${ }^{1 *}$ (D) Mesude DiNÇ² ${ }^{(D)}$, Fethiye ÖZBERK ${ }^{3}$ (D) \\ ${ }^{1}$ Harran Üniversitesi Ziraat Fakültesi Tarla Bitkileri Bölümü, Şanlıurfa/TÜRKIYE \\ ${ }^{2}$ Harran Üniversitesi Fen Bilimleri Enstitüsü YL Öğrencisi, Şanlıurfa/TÜRKIYE \\ ${ }^{3}$ Akçakale Meslek Yüksek Okulu, Şanlıurfa/TÜRKiYE
}

\section{To cite this article:}

Özberk, i., Dinç, M. \& Özberk, F. (2019). Bazı ekmeklik buğday yalın çeşit ve tarla paçallarının tarımsal özellikler, kalite ve karlılık bakımından incelenmesi. Harran Tarım ve Gıda Bilimleri Dergisi, 23(2): 196205. DOI:

10.29050/harranziraat.440011

Address for Correspondence: Irfan ÖZBERK

e-mail:

ozberki@harran.edu.tr

Received Date:

03.07.2018

Accepted Date:

12.10.2018
Öz

Bu çalışmada Güneydoğu Anadolu Bölgesinde yetiştirilen yerli ve yabancı orijinli çeşitlerin farklı oranlar ve kombinasyonlarda karışım olarak ekilerek hem tarımsal özellikleri hem de elde edilen karışım buğdayların değirmencilik ve fırıncılık özellikleri belirlenerek karışım halinde ekimin çiftçiler için karlı olarak uygulanabilirliği araştırılmıştır. Deneme GAPEYAM Koruklu İstasyonunda 7 farklı çeşit ve bunların paçallarından oluşan 8 konu ile toplamda 15 konu olarak 2016-2017 üretim yılında tesadüf blokları deneme desenine göre 4 tekerrürlü olarak yürütülmüştür. Ölçülen çeşitli tarımsal özellikler varyans ve korelasyon analizleri yolu ile incelenmiştir. Araştırma sonuçlarına göre verim konusunda yalın çeşitlerin $(684 \mathrm{~kg} / \mathrm{da})$ karışımlardan $(674 \mathrm{~kg} / \mathrm{da})$ daha verimli olduğu ancak karışımlardan $\mathrm{K}_{1}(706 \mathrm{~kg} / \mathrm{da})$ ve $\mathrm{K}_{4}(710$ $\mathrm{kg} / \mathrm{da})$ konularının genel ortalamadan $(679 \mathrm{~kg} / \mathrm{da})$ daha yüksek verim verdiği anlaşılmıştır. Ana verim öğeleri bakımından karışımların yalın çeşitlerden daha üstün olduğu görülmüştür. Kalite özelliklerinden un randımanının karışımlarda $(\% 69.4)$ yalın çeşitlerden $(\% 68,8)$ daha yüksek olduğu, kül oranın karışımlarda $(\% 0.878)$ yalın çeşitlerden $(\% 0.887)$ daha düşük olduğu anlaşılmıştır. Buna karşın protein oranı ortalamasının, karışım ve yalın çeşit ortalamalarında aynı olduğu (\% 14.3) tespit edilmiştir. Gluten miktarının karışımlarda (\%29.9.) yalın çeşitlerden (\% 30.7.) daha düşük olduğu, sedimantasyon değerlerinin karışımlarda(47 ml) yalın çeşitlerden (47.2 ml.) daha düşük olduğu anlaşılmıştır. Hamur üretiminden 90 dakika sonra ölçülen enerji değerlerine göre en yüksek enerji değerleri $K_{6}\left(61.8 \mathrm{~cm}^{2}\right)$ ve $K_{7}\left(61.2 \mathrm{~cm}^{2}\right)$ karışımlarından elde edilmiştir. Verim ile metrekaredeki başak sayısı $\left(-0.486^{* *}\right)$, başakta başakçık sayısı $\left(-0.333^{* *}\right)$, olgunlaşma gün sayısı $\left(-0.351^{* *}\right)$, çıkış gün sayısı $\left(-0.334^{* *}\right)$, başakta tane ağılığı $\left(-0.334^{* *}\right)$ ve bin tane ağırlığı $(-0.349 * *)$ arasında istatistiksel olarak önemli $(P<0.01)$ negatif korelasyonlar saptanırken, hektolitre ağırlığı ile $(0.359 * *)$ önemli pozitif korelasyon $(P<0.01)$ bulunmuştur. Karışımların ortalama gelirleri $613 \mathrm{TL} / \mathrm{da}$ iken, yalın çeşitlerin ise $629 \mathrm{TL} / \mathrm{da}$ olarak bulunmuştur. Karışımlara ve yalın çeşitlere ait ortalamalar göz önünde bulundurulduğunda, karışımlarda en yüksek gelir $\mathrm{K}_{4}$ (\% 30 Adana $99+\% 50$ Sagittario + \% 20 Odeskaya) konusundan elde edilmiştir ( $650 \mathrm{TL} / \mathrm{da}$ ). $\mathrm{K}_{4}$ konusunun verim, kalite ve dekara gelir yönünden yalın çeşitler ile rekabet edebileceği ve çiftçiye tavsiye edilebileceği anlaşılmıştır.

Anahtar Kelimeler: Ekmeklik buğday, Tarla paçalları, Tarımsal ve kalite özellikleri, Karlılık

\section{ABSTRACT}

This study aimed to investigate some agronomical traits, milling and dough properties for some mixtures of bread wheat varieties and assess the profitability of promising mixtures. Field experiments were carried out at the Koruklu station of Extension, Research and training Center of Southeastern Anatolia Project in Şanliurfa. Seven individual and eight mixtures were tested employing randomized complete block design with 4 replications. Some agronomical traits were tested through analysis of variance and Pearson coefficients of correlation. It was found that pure varieties gave higher average grain yield $(684 \mathrm{~kg} / \mathrm{da})$ than mixtures $(674$ $\mathrm{kg} / \mathrm{da}$ ). Mixture number 1 and 4 gave higher grain yields than the average of pure lines with 
706 and $710 \mathrm{~kg} / \mathrm{da}$ respectively. Mixtures were higher in rank for major yield components. Some dough rheological properties of mixtures such as ash content (\%), gluten (\%), sedimantation $(\mathrm{ml})$ were lower than those of püre varieties. Flour ratio (\%)of mixtures was only trait giving higher value than that of pure varieties. $K_{6}\left(61.8 \mathrm{~cm}^{2}\right)$ and $\mathrm{K}_{7}\left(61.2 \mathrm{~cm}^{2}\right)$ mixtures gave the highest energy scores 90 minutes after dough production.The coefficients of correlation grain yield vs. number of spike per unit area $\left(r=-0.486^{* *}\right)$, number of spikelet spike ${ }^{-1}\left(r=-0.333^{* *}\right)$, number of days to maturity $\left(r=-0.351^{* *}\right)$, number of days to emergence $\left(r=--0.334^{* *}\right)$, grain weight spike ${ }^{-1}\left(r=-0.334^{* *}\right)$, and 1000 kernel weights $(r=-0.349 * *)$ were found to be negative and significant. But this turned out to be pozitive and significant for hectoliter weight $\left(r=0.359^{* *}\right)$. Average net return of püre varieties was higher than that of mixtures with $629 \mathrm{TL} \mathrm{da}^{-1}$ and $613 \mathrm{TL} \mathrm{da}^{-1}$ respectively. Highest net return was obtained from Mixture 4 (30\% Adana-99+ 50\% Sagittario+ 20\% Odeskaya) with 650 TL da ${ }^{-1}$. Taking into account for grain yield and quality characteristics, Mixture 4 can compete with pure varieties and be recommended for farmers in the region.

Key Words: Bread wheat, Field mixtures, Agronomical and quality characteristics, Profitability

\section{Giriş}

Dünya genelinde son 30 yıldır yaygın bir şekilde uygulanmakta olan çeşitlerin karışım halinde ekilmesi tahıl üretimi açısından bazı avantajları beraberinde getirmektedir (Mille ve ark., 2006; Asghar ve ark., 2011; Smith ve ark., 2014). Çeşitlerin birlikte ekilmesi ile bazı çeşitlerin üstün yönleri karışım ortamında öne çıkarılırken, diğer çeşidin ise negatif yönleri bastırılmaya çalışılmaktadır (Cox ve ark., 2004; Dai ve ark. 2012). Bu yöntem ile daha sağlıklı gelişen bitkinin doğal olarak veriminde artış meydana gelmesi çiftçinin kar oranını artırmaktadır. Buğday ve arpa gibi tek yıllık bitkilerin karışım halinde ekilmesi ile birlikte; (I) bitkinin hastalıklara karşı direnci artmakta, (II) bitkinin hastalıklara karşı direncine bağlı olarak verimi artmakta, (III) tane kalitesi artmakta, (IV) farklı yıllarda meydana gelen meteorolojik farklılıklara rağmen verim stabil kalmaktadır (Faraji, 2011). Çeşitlerin karışım halinde ekilmesi eskiden beri uygulanan bir yöntem olmasına rağmen, çeşitlerin ekim oranları, seçilmesi ve karışımların oluşturulması hala güncel ve önemli bir konudur (Dai, 2012). Seçilen çeşitlerin bir kısım özelliklerinin diğer ekilen çeşitten daha iyi olması göz önünde bulundurularak karışımlar oluşturulmakta ve her ekilen çeşidin bir de karışım oranları gündeme gelmektedir. Bu yüzden her ekoloji ve toprak özellikleri için karışım ekim denemeleri güncellenmeli ve verimli çeşitler ile yeniden karışımların oluşturulması ile çeşitlerin üstün özellikleri ile diğer çeşitlerin zayıf yönlerinin gizlenmesi söz konusu olmaktadır. Cheema ve ark. (1988), Pakistan'da farklı buğday genotiplerinin paçal yapılarak ekilmesi sonucunda verim ve kalite parametrelerinin nasıl değiştiğini gözlemlemek için yaptıkları çalışmada on farklı genotipin karışımı ekilmiştir. Araştırmacılar, çeşit karışımlarının birlikte ekilmesi ile birlikte buğday veriminde \% 18,8'e kadar yükselme olduğunu, buğday çeşitlerinin karışım olarak ekilmesi ile birlikte ürün veriminin artırılabileceğini belirtmişlerdir. Mundt ve Schmitt (1995) Amerika'nın Oregon Eyaletinde dört farklı buğday çeşidi ile düşük ve yüksek hastalık şartlarında yetiştirilen buğday karışımlarının verim ve hastalık için tepkisini araştırdıkları çalışmada; hastalığa dayanıklı çeşitlerin paçallarında hastalık oranının daha az olduğunu ve verimlerde önemli değişikliklerin olmadığını belirtmişlerdir. Jackson ve Wennig (1997) Kalifornia'da yetiştirilen Septoria tritici'ye karşı hassasiyeti düşük, verimi yüksek, yatmaya dayanıklı ve tane kalitesi düşük olan Yolo isimli buğday çeşidi ve tane verimi yüksek, Septoria tritici'ye hassasiyeti yüksek, yatmaya karşı hassas ve yüksek tane kalitesi olan Serra isimli iki buğday çeşidini 0:1, 1:2, 1:1, 2:1 ve 1:0 oranlarında karıştırarak ekimini yaptıkları çalışmada bitkilerinin hastalıklara karşı dayanıkııı̆ını araştırmışlardır. Araştırmacılar yatma olduğu sezonda Serra'nın tek ekildiği durumda yattığını, Yolo ile birlikte ekildiğinde yatma olmadığını; hastalık olduğunda tek başına ekilen Serra'nın hastalıktan etkilendiğini, karışık ekildiğinde ise hastalığın daha az olduğunu; tek başına ya da karışık ekim sonrasında verimde önemli bir değişiklik olmadığını belirtmişlerdir. Gallant ve ark. (2001) Amerika'nın Maine Eyaletinde 6 ekmeklik buğday çeşidi kullanılarak oluşturulan 15 çeşit karışımının 33 farklı 
lokasyonda karışık buğday ekiminin verime olan etkisini araştırdıkları çalışma sonucuna göre; lokasyonlar ortalaması olarak karışımların dane verimlerinin, karışımları oluşturan yalın çeşit verimlerine göre \% 1.5 daha fazla olduğunu; protein oranı yönünden karışımlar ve saf çeşit ortalamaları arasında fark olmadığını, tane verimi ve protein oranı yönünden karışımların performansları ile karışımı oluşturan iki saf hattın ortalaması arasında önemli derecede korelasyon olduğunu belirtmişlerdir. Dai ve ark. (2012), Amerika'nın Minnesota eyaletinde buğday çeşitlerinin karışım olarak ekilmesi ile bazı çeşitlerin iyi özelliklerini öne çıkararak zayıflıklarını gölgelemek amacıyla yaptıkları çalışma sonuçlarına göre; yağışa dayalı koşularda karışımların saf çeşitlere oranla verimi \% 3.2 oranında arttığını, 6 farklı çeşit ile oluşturulan 3 farklı kombinasyon sonucuna göre; yapılan regresyon analizlerinde tane verimi, protein içeriği, yatmaya ve paslara mukavemet ile çeşit karışımları arasında doğrusal (olumlu) ilişki bulunduğunu, çeşit tohumlarını karıştırmanın düşük teknoloji olarak değerlendirildiğini ancak verimde meydana gelen değişkenliğin bu yolla azaltılabileceğini belirtmişlerdir. Kaczmarek ve Matsiak (2017), Polonya'nın Poznan kentinde iki farklı buğday çeşidi ve bunların karışım olarak ekimi üzerine farklı herbisit uygulamalarının yabancı ot çıkışı, verim ve tane verimi, protein içeriği ve nişasta içeriği üzerine etkilerini araştırdıkları çalışmada; karışım halinde (\% 50 - \% 50) ekilen buğdayın veriminin arttığını, yabancı ot çıkışının azaldığını ve yabancı ot ile mücadelede gerekli kimyasal miktarının önemli miktarda azaldığını belirtmişlerdir. Koçak ve ark. (1993), piyasada kullanılan buğday çeşitlerinin değirmencilik özelliklerini artırmak için yaptıkları çalışmada Gerek 79, Malabadi, Penjamo 62, Orso çeşitleri iyi kaliteli olarak bilinen Bezostaya, Lancer, Kıraç 66 ve Köse 220/39 çeşitleri ile \% 20, $\% 40, \% 60$ ve \% 80 oranında öğütülmeden önce karıştırılmış, un verimi ve kül miktarları değerlendirilmiştir. Araştırma sonuçlarına göre Bezostaya çeşidinin Gerek 79, Malabadi ve Penjamo 62 çeşitlerinin un verimlerini, Kıraç 66 çeşidinin ise Gerek 79, Penjamo 62 ve Orso çeşitlerinin un verimleri ve kül miktarlarını iyileştirdiği belirlenmiştir. Hayta ve Çakmaklı (2001), piyasada yaygın olarak kullanılan ekmeklik buğday çeşitlerinden olan Cumhuriyet 75, Gerek 79, Atay 85, Gönen, İzmir 85, Kırkpınar 79, Bezostaya ve Amerikan yumuşak kışlık kırmızı buğday çeşidi ve Arjantin kökenli ticari buğday çeşidinin paçallarından elde ettikleri hamurların; sedimantasyon değerinin 22,5 - 30,5 ml arasında, yaş gluten miktarının \% 22,8 - 28,4 arasında, su absorbsiyonunun \% 57,2 - 64,2 arasında, hamur yoğurma süresinin 1,2 - 4.00 dakika arasında, hamur stabilitesi değerinin 0.30 - 4 arasında, yumuşama derecesinin 110 - 190 BU arasında olduğunu, uzamaya karşı direnç değerinin 157 $482 \mathrm{BU}$ arasında, uzama kabiliyetinin $119-143$ $\mathrm{mm}$ arasında, enerji değerinin 33,0 - 75,6 arasında olduğunu belirtmişlerdir. Bu çalışmada bölge değirmenlerinin kullandığı buğday paçallarının tarla koşullarında oluşturulması ve bu yolla verim ile kalitede stabilitenin sağlanması öngörülmüş, karlı karışımların belirlenerek çiftçiye önerilmesi amaçlanmıştır.

\section{Materyal ve Metot}

\section{Toprak özellikleri}

Deneme Harran Ovasında GAP Tarımsal Araştırma Enstitüsü Müdürlüğüne ( GAPTAEM) bağlı Serince Araştırma İstasyonunda 2016-2017 üretim sezonunda yürütülmüştür. Deneme alanından $0-30 \mathrm{~cm}$ derinlikten alınan toprak numunesinin fiziksel ve kimyasal özellikleri GAPTAEM Toprak Laboratuvarında belirlenmiş ve Çizelge 1'de verilmiştir.

Çizelge 1. Deneme kurulan arazinin toprak özellikleri Table1.Soil characteristics of experimental area

\begin{tabular}{ccccccc}
\hline $\begin{array}{c}\mathrm{pH} \\
\text { (Sat) }\end{array}$ & $\begin{array}{c}\mathrm{EC} \\
(\mathrm{dS} / \mathrm{m})\end{array}$ & $\begin{array}{c}\mathrm{OM} \\
(\%)\end{array}$ & $\begin{array}{c}\text { Kireç } \\
(\%)\end{array}$ & $\begin{array}{c}\mathrm{P} \\
(\mathrm{mg} / \mathrm{kg})\end{array}$ & $\begin{array}{c}\mathrm{K} \\
(\mathrm{mg} / \mathrm{kg})\end{array}$ & $\begin{array}{c}\text { DTPA- } \\
(\mathrm{mg} / \mathrm{kg})\end{array}$ \\
\hline 7.42 & 0.54 & 2.57 & 25.3 & 4.43 & 146 & 4.43 \\
\hline
\end{tabular}

Araştırma alanının toprak yapısı genel olarak killi olup, organik madde miktarı, yarayışlı fosfor, demir ve potasyum miktarı yeterli olan alüvial topraktır. Toprak yapısı genel olarak bitki beslemeye uygun olup, düzenli gübreleme ile verimli yetiştiricilik yapılması mümkündür. 
iklim özellikleri

Araştırma alanı kurak iklime sahip olup yazları oldukça az yağış almaktadır. Bölge karasal geçit iklime sahip olduğu için sulama olmaksızın tarım yapılması güç olmaktadır. Bölgede var olan derin kuyular ve sulama kanalları ile buğday, mısır ve pamuk gibi serin ve sıcak iklim bitkilerinin tarımı yapılabilmektedir. Araştırma alanının yağış ve sıcaklık verileri aşağıda verilmiştir.

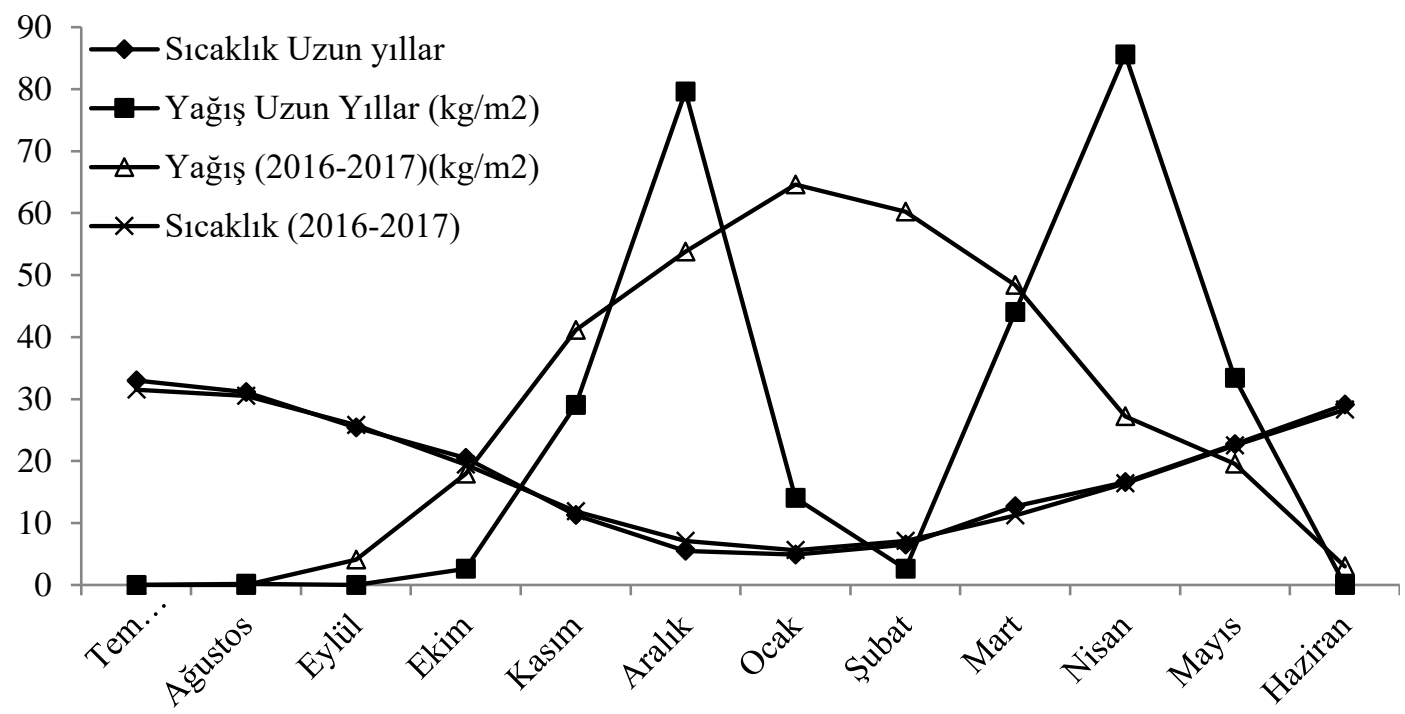

Şekil 1. Araştırma alanının deneme yılı (2016-2017) ve uzun yıllara ait yağış ve sıcaklık verileri

Figure 1. Meteorological data both 2016-17 and long term averages in the experimental location.

Denemede kullanılan yalın çeşit ve karışımlar:

Çalışmada kullanılan yalın çeşitler ve paçallar Diyarbakır ilinde un üreten değirmenlere yapılan ziyaretlerde elde edilen bilgiler ışığında seçilmişlerdir.

1. $\mathrm{K}_{1}: \% 50$ Ceyhan $99+\% 50$ Sagittario

2. $\mathrm{K}_{2}: \% 35$ Ceyhan $99+\% 35$ Sagittario $+\% 30$ Pehlivan

3. $\mathrm{K}_{3}: \% 25$ Ceyhan $99+\% 40$ Sagittario $+\% 15$ Pehlivan $+\% 20$ Bezostaya

4. $\mathrm{K}_{4}: \% 30$ Adana $99+\% 50$ Sagittario $+\% 20$ Odeskaya

5. $\mathrm{K}_{5}$ : \%28 Adana $99+\% 72$ Pehlivan

6. $\mathrm{K}_{6}: \% 30$ Ceyhan $99+\% 30$ Sagittario $+\% 10$ Pehlivan $+\% 10$ Bezostaya $+\% 20$ Golia

7. $\mathrm{K}_{7}: \% 40$ Golia + \% 30 Sagittario+ \% 30 Odeskaya

8. $\mathrm{K}_{8}$ : \%30 Adana $99+50$ Pehlivan $+\% 20$ Bezostaya

9. Ç1: Ceyhan 99

10. Ç2: Adana 99

11. Ç3: Pehlivan

12. Ç4: Sagittario

13. Ç5: Bezostaja

14. Ç6: Odeskaya

15. Ç7: Golia

\section{Yöntem}

Deneme 7 farklı çeşit ve bunların paçallarından oluşan 8 konu toplamda 15 konu olarak 20162017 üretim yılında tesadüf blokları deneme desenine göre 4 tekerrürlü olarak yürütülmüştür.

\section{Deneme uygulamaları}

Denemenin kurulduğu arazide ön bitki olarak mısır ekilmiş, hasat sonrasında pulluk ile yüzlek işleme yapıldıktan sonra, kazayağı ile ikileme yapılıp, sonra goble disk çekilerek tohum yatağı hazırlanmış ve parsel ekim mibzeri ile ekimler yapılmıştır. Deneme parselleri 1.2×6 metre olacak şekilde oluşturularak buğday parsel ekim mibzeri ile metre kareye 550 tane düşecek şekilde 1000 tane ağırlıkları ve karışım oranları göz önünde bulundurularak ekilmiş ve ekimle birlikte saf olarak $6 \mathrm{~kg} / \mathrm{da} \quad \mathrm{N}, 6 \mathrm{~kg} / \mathrm{da} \quad \mathrm{P}_{2} \mathrm{O}_{5}$ gübresi verilmiştir. Üst gübre olarak $8 \mathrm{~kg} / \mathrm{da} \quad \mathrm{N}$ uygulanmıştır. Deneme süresince kemirgenler, yabancı ot ve hastalıklara karşı ilaçlama yapılıp, Nisan ayı ortasında toprak nem analizine göre sulanmıştır. Materyal hasat olgunluğuna gelince kenar tesiri çıkarıldıktan sonra parsel biçerdöveri ile hasat edilmiştir. 
Araştırmada Gözlenen ve Ölçülen Karakterler

\section{Tarımsal özellikler}

Çıkış gün sayısı: Parseldeki bitkilerin ekim tarihinden itibaren \% 50 sinin çim kınının ucunun toprak yüzeyinde görüldüğü sürenin gün olarak belirlenmesiyle bulunmuştur.

$M^{2}$ de başak sayısı (Adet $/ \mathrm{m}^{2}$ ):Hasat öncesi, bir sıra üzerindeki $1 \mathrm{~m}$ uzunluk ve $20 \mathrm{~cm}$ genişlik üzerindeki bitkiler ile yapılıp, daha sonra 5 ile çarpılarak 1 metrekarelik alandaki başak sayısı hesaplanmıştır.

Olgunlaşma gün sayısı (gün):Bitkilerin ekim tarihinden itibaren olgunlaşmasına kadar geçen süre gün olarak hesaplanarak elde edilmiştir.

Başakta başakçık sayısı (Adet/başak): Her parselden alınan 10'ar adet başak örneklerinde başaktaki başakçık sayısının sayılıp ortalamalarının alınması ile belirlenmiştir.

Başakta tane ağırlığı (g/başak):10 ana sap başağından elde edilen tanelerin tartılmasıyla ve ortalaması alınmasıyla elde edilmiştir.

Bin tane ağırlığı (g):Her parselden elde edilen tanelerden rastgele $4 \times 100$ tane sayılarak $0.01 \mathrm{~g}$ duyarlııktaki terazide tartılıp, ortalamaların 10 ile çarpılmasıyla hesaplanmıştır.

Hektolitre ağırlığı (kg/100 L ):Her parselden alınan örneklere ait hektolitre değeri NID (NID Im model 9500) cihazında kg olarak tespit edilmiştir.

Verim ( $\mathrm{kg} / \mathrm{da})$ :Her parselden parsel biçerdöveri ile hasat edilen buğdaylar laboratuvara getirilip tartıldıktan sonra bir dekardaki buğday verimi (kg/da) hesaplanmıştır.

\section{Değirmencilik özellikleri}

Un randımanı (\%): Temizlenmiş ve tavlanmış 1 kg buğdaydan elde edilen un \% olarak hesaplanarak elde edilmiştir.

Kül oranı (\%):ICC-standart no:104 metoduna göre kül fırınında $900{ }^{\circ} \mathrm{C}$ 'de yakılarak tayin edilmiştir (Anonim,2000).

Protein (\%):Her parselden alınan örneklere ait protein oranı NID (NID Im model 9500) cihazında $\%$ olarak tespit edilmiştir.

Sedimantasyon (ml):Her parselden alınan örneklerin sedimantasyon değerleri NID cihazında $\mathrm{ml} / \mathrm{l}$ cinsinden tespit edilmiştir.

Yaş gluten (\%):ICC- standart no: 106 metoduna göre yapılmıştır (Anonim, 2000).

\section{Hamur reolojik özellikleri}

Enerji değeri $\left(\mathrm{cm}^{2}\right)$ :Ekstensoğrafın ürettiği kurvenin planimetrik sahası olup $\mathrm{cm}^{2}$ ile değerlendirilmiştir.

\section{Karlılık analizleri}

Denemede yer alan tüm karışım ve yalın çeşitlere aynı girdiler uygulandığı için değişen masraflar dikkate alınmadan çeşit veya karışımların verim değerleri $(\mathrm{kg} / \mathrm{da})$ ile o çeşit veya karışımlara verilen pazarlama fiyatları $(\mathrm{TL} / \mathrm{kg})$ çarpılarak dekara net getirisi yüksek (TL/da)çeşit veya karışımlar belirlenmiştir.

\section{Istatistik değerlendirme}

Deneme boyunca gözlemlenen parametreler tesadüf blokları deneme desenine göre JMP-5 istatistik programında varyans analizine tabi tutulmuş ve ortalamalar arasındaki farklılıklar \% 5 önem seviyesinde Duncan testi ile karşılaştırılmış ve elde edilen parametreler arasında korelasyonlar belirlenmiştir (Yurtsever, 1984).

\section{Bulgular ve Tartışma}

\section{Incelenen bazı tarımsal özellikler}

Çalışmada ölçülen veya gözlenen tüm karakterlere ait çeşit veya karışımların F değerleri ve istatistiksel önemlilikleri, karışım ve yalın çeşit ortalamaları ve Duncan testine göre oluşan gruplar Çizelge 2, 3 ve 4 'de verilmiştir. Çıkış gün sayısı, $\mathrm{m}^{2}$ de başak sayısı, olgunlaşma gün sayısı, başakta başakçık sayısı, başakta tane ağırlığı, hektolitre ve 1000 tane ağırlığı bakımından tüm yalın çeşit ve karışımlar istatistiksel önemde birbirlerinden farklı bulunmuşlardır. Varyans analiz sonuçlarına göre yukarıda belirtilen karakterler için karışımlar ve yalın çeşitlerin ortalamaları arasında istatistiksel önemde bir fark görülmemiştir (Çizelge 2.). 
Çizelge 2. Bazı tarımsal karakterlere ait istatistik değerler ile ortalama değerler ve oluşan gruplar Table 2. Statistics and means/grouping of some traits under study

\begin{tabular}{|c|c|c|c|c|c|c|c|}
\hline $\begin{array}{l}\text { Karışım ve } \\
\text { Çeşitler } \\
\text { Mixtures } \\
\text { and pure } \\
\text { varieties }\end{array}$ & $\begin{array}{c}\text { Çıkış gün } \\
\text { sayısı (Gün) } \\
\text { Number of } \\
\text { germination } \\
\text { days }\end{array}$ & $\begin{array}{c}\mathrm{m}^{2} \mathrm{de} \\
\text { başak } \\
\text { sayısı } \\
\text { (Adet) } \\
\text { Number of } \\
\text { spike per } \\
m^{2}\end{array}$ & $\begin{array}{l}\text { Olgunlaşma gün } \\
\text { sayısı (Gün) } \\
\text { Number of days } \\
\text { to maturity }\end{array}$ & $\begin{array}{l}\text { Başakta } \\
\text { başakçık sayısı } \\
\text { (adet) } \\
\text { Number of } \\
\text { spikelet } \\
\text { perspike }\end{array}$ & $\begin{array}{l}\text { Başakta } \\
\text { tane ağırlığı } \\
\text { (g) } \\
\text { Spike } \\
\text { weight(g) }\end{array}$ & $\begin{array}{l}\text { Hektolitre } \\
(\mathrm{kg}) \\
\text { Hectoliter } \\
\text { weight }(\mathrm{kg})\end{array}$ & $\begin{array}{l}\text { Bin tane } \\
\text { ağırlığı (g) } \\
1000 \text { kernel } \\
\text { weights }(g)\end{array}$ \\
\hline $\mathrm{K}_{1}$ & $27.38 \mathrm{c}$ & $477 \mathrm{c}$ & $203 \mathrm{bcd}$ & $16.0 \mathrm{cde}$ & $1.379 a b$ & $83.40 \mathrm{~b}$ & $38.13 \mathrm{fgh}$ \\
\hline $\mathrm{K}_{2}$ & $27.38 \mathrm{c}$ & 467 e & $204 a b c$ & $17.0 \mathrm{abc}$ & $1.242 \mathrm{bcd}$ & $83.20 \mathrm{~b}$ & 40.13 cdef \\
\hline $\mathrm{K}_{3}$ & $28.38 b$ & 442 I & $204 a b c$ & $17.5 a b$ & $1.138 \mathrm{def}$ & $83.10 \mathrm{bc}$ & 40.00 cdef \\
\hline $\mathrm{K}_{4}$ & $27.38 \mathrm{c}$ & 4271 & 200 efg & 15.5 def & $1.310 a b c$ & $83.70 a b$ & $39.25 \mathrm{efg}$ \\
\hline $\mathrm{K}_{5}$ & $27.38 \mathrm{c}$ & $462 \mathrm{f}$ & 202 cde & $17.0 \mathrm{abc}$ & $1.242 \mathrm{bcd}$ & $83.80 a b$ & $42.94 \mathrm{ab}$ \\
\hline $\mathrm{K}_{6}$ & $27.38 \mathrm{c}$ & $472 \mathrm{~d}$ & $204 a b c$ & $16.5 \mathrm{bcd}$ & $1.173 \mathrm{cde}$ & $83.23 b c$ & $39.31 \mathrm{efg}$ \\
\hline $\mathrm{K}_{7}$ & $27.38 \mathrm{c}$ & $432 \mathrm{k}$ & $198 \mathrm{~g}$ & 15.0 ef & 1.070 efg & 83.48 bc & $36.39 \mathrm{~h}$ \\
\hline $\mathrm{K}_{8}$ & $27.38 \mathrm{c}$ & $482 \mathrm{~b}$ & $203 \mathrm{bcd}$ & $17.5 a b$ & $1.310 \mathrm{abc}$ & 83.38 bc & $42.00 \mathrm{bc}$ \\
\hline$\bigodot_{1}$ & $28.38 \mathrm{~b}$ & $457 \mathrm{~g}$ & $204 a b c$ & $17.3 \mathrm{abc}$ & $1.414 \mathrm{a}$ & $83.55 b c$ & $37.45 \mathrm{gh}$ \\
\hline$C_{2}$ & $27.38 \mathrm{c}$ & $492 \mathrm{a}$ & 201 def & $17.1 \mathrm{abc}$ & $1.345 a b$ & $84.70 \mathrm{a}$ & $37.78 \mathrm{gh}$ \\
\hline$C_{3}$ & $28.38 b$ & $472 \mathrm{~d}$ & 202 cde & $16.7 \mathrm{abcd}$ & $1.173 \mathrm{cde}$ & $83.78 b$ & $44.50 \mathrm{a}$ \\
\hline$C_{4}$ & $26.38 d$ & $452 \mathrm{~h}$ & $205 a b$ & 15.0 ef & $1.142 \mathrm{bcd}$ & $83.40 \mathrm{bc}$ & 39.50 defg \\
\hline$C_{5}$ & $29.38 \mathrm{a}$ & $492 \mathrm{a}$ & $206 a$ & $18.0 \mathrm{a}$ & $1.035 \mathrm{fg}$ & $82.53 \mathrm{bc}$ & 41.25 bcde \\
\hline $\mathrm{Ç}_{6}$ & $29.38 a$ & $412 \mathrm{~m}$ & $199 \mathrm{fg}$ & $14.5 \mathrm{f}$ & $1.035 \mathrm{fg}$ & $82.50 \mathrm{c}$ & $41.56 \mathrm{bcd}$ \\
\hline$C_{7}$ & $27.38 \mathrm{c}$ & $437 \mathrm{j}$ & $193 \mathrm{~h}$ & $16.0 \mathrm{cde}$ & $1.000 \mathrm{~g}$ & $83.70 a b$ & 33.20 I \\
\hline $\begin{array}{l}\text { Karışım } \\
\text { Ort. }\end{array}$ & 27.5 & 457 & 202 & 16.5 & 1.233 & 83.4 & 39.8 \\
\hline Çeşit Ort. & 28.1 & 459 & 202 & 16.3 & 1.163 & 83.4 & 39.3 \\
\hline Genel Ort. & 27.8 & 458 & 202 & 16.4 & 1.201 & 83.4 & 39.6 \\
\hline$P<0.05$ & 0.000 & 0.000 & 0.000 & 0.000 & 0.000 & 0.000 & 0.000 \\
\hline$\% \mathrm{VK}$ & 3.27 & 5.17 & 1.71 & 7.63 & 12.3 & 0.78 & 7.51 \\
\hline F hesap & $11.969 * *$ & $478 * *$ & $21.3^{* *}$ & $6.744^{* *}$ & $9.552 * *$ & $5.551 * *$ & $17.102 * *$ \\
\hline
\end{tabular}

Çizelge 3. Bazı değirmencilik ve hamur reolojik özelliklerine ait istatistik değerler ile ortalamalar ve oluşan gruplar Table 3.Some statistics, means /grouping of some milling and dough rheological properties of some traits under study

\begin{tabular}{|c|c|c|c|c|c|c|c|}
\hline $\begin{array}{l}\text { Karışım ve } \\
\text { Çeşitler } \\
\text { Mixtures and } \\
\text { pure varieties }\end{array}$ & $\begin{array}{l}\text { Un randımanı } \\
\text { (\%) } \\
\text { Flour ratio } \\
\text { (\%) }\end{array}$ & $\begin{array}{l}\text { Kül oranı } \\
\text { (\%) } \\
\text { Ash ratio } \\
\text { (\%) }\end{array}$ & $\begin{array}{l}\text { Protein } \\
\text { (\%) } \\
\text { Protein } \\
\text { (\%) }\end{array}$ & $\begin{array}{l}\text { Sedimantasyon } \\
\text { (Zeleny) (ml) } \\
\text { Zeleny sedimantation } \\
(\mathrm{ml})\end{array}$ & $\begin{array}{l}\text { Yaş } \\
\text { gluten (\%) } \\
\text { Wet } \\
\text { gluten } \\
(\%)\end{array}$ & $\begin{array}{l}\text { Enerji değeri } \\
\left(\mathrm{cm}^{2}\right) \\
\text { Energy }\left(\mathrm{cm}^{2}\right) \\
\text { 45. Dk }\end{array}$ & 90.Dk \\
\hline $\mathrm{K}_{1}$ & 65.73 def & $0.858 \mathrm{bcd}$ & 14.15 cdef & $45.50 \mathrm{cde}$ & 29.58 & $40.8 \mathrm{e}$ & $33.8 \mathrm{f}$ \\
\hline $\mathrm{K}_{2}$ & $71.68 \mathrm{abc}$ & $0.871 \mathrm{bcd}$ & $14.18 \mathrm{cdef}$ & 45.75 cde & 29.55 & - & - \\
\hline $\mathrm{K}_{3}$ & $70.73 \mathrm{abcd}$ & 0.926 bc & $14.73 b$ & $50.50 \mathrm{~b}$ & 30.83 & $53.0 \mathrm{~cd}$ & $48.5 \mathrm{c}$ \\
\hline $\mathrm{K}_{4}$ & 68.43 bcde & $0.870 \mathrm{bcd}$ & $13.98 \mathrm{efg}$ & 43.75 def & 29.15 & $57.8 \mathrm{bc}$ & $45.0 \mathrm{~d}$ \\
\hline $\mathrm{K}_{5}$ & $73.83 a b$ & $0.854 \mathrm{bcd}$ & $13.93 \mathrm{efg}$ & $44.75 \mathrm{de}$ & 29.03 & - & - \\
\hline $\mathrm{K}_{6}$ & $67.25 \mathrm{cdef}$ & $0.889 \mathrm{bcd}$ & $14.38 \mathrm{cde}$ & $47.75 \mathrm{bcd}$ & 30.08 & $73.0 \mathrm{a}$ & $61.8 \mathrm{a}$ \\
\hline $\mathrm{K}_{7}$ & 67.68 cde & $0.937 a$ & $14.60 \mathrm{bc}$ & 49.25 bc & 30.53 & $73.5 \mathrm{a}$ & $61.2 \mathrm{a}$ \\
\hline $\mathrm{K}_{8}$ & $71.83 a b c$ & $0.818 d$ & $14.45 \mathrm{bcd}$ & $49.00 \mathrm{bc}$ & 30.18 & $19.5 \mathrm{f}$ & $12.8 \mathrm{~h}$ \\
\hline$C_{1}$ & 62.88 ef & $0.842 \mathrm{~cd}$ & $13.63 \mathrm{gh}$ & 42.00 ef & 28.35 & $69.5 \mathrm{a}$ & $16.5 \mathrm{~g}$ \\
\hline$C_{2}$ & $61.80 \mathrm{fg}$ & $0.840 \mathrm{~cd}$ & $13.40 \mathrm{~h}$ & $40.25 \mathrm{f}$ & 28.83 & $61.0 \mathrm{~b}$ & $48.8 \mathrm{c}$ \\
\hline$C_{3}$ & $74.65 \mathrm{a}$ & $0.827 \mathrm{~d}$ & $13.83 \mathrm{fgh}$ & 43.75 def & 33.80 & - & - \\
\hline$C_{4}$ & $75.80 \mathrm{a}$ & $0.892 \mathrm{bcd}$ & $14.68 \mathrm{~b}$ & $49.00 \mathrm{bc}$ & 30.75 & $61.5 \mathrm{~b}$ & $57.5 \mathrm{~b}$ \\
\hline$C_{5}$ & $75.38 \mathrm{a}$ & $0.865 \mathrm{bcd}$ & $16.10 \mathrm{a}$ & $63.00 \mathrm{a}$ & 33.90 & $47.8 \mathrm{~d}$ & $38.0 \mathrm{e}$ \\
\hline$C_{6}$ & 73.75ab & $0.917 \mathrm{bc}$ & $13.76 \mathrm{fgh}$ & 42.50 ef & 28.65 & $18.75 \mathrm{f}$ & $17.0 \mathrm{~g}$ \\
\hline$C_{7}$ & $57.00 \mathrm{~g}$ & $1.028 \mathrm{a}$ & $14.55 \mathrm{bc}$ & $50.00 \mathrm{~b}$ & 30.40 & $34.5 \mathrm{e}$ & $17.5 \mathrm{~g}$ \\
\hline Karışım Ort. & 69.6 & 0.878 & 14.3 & 47.0 & 29.9 & 39.7 & 32.9 \\
\hline Çeşit Ort. & 68.8 & 0.887 & 14.3 & 47.2 & 30.7 & 41.9 & 27.9 \\
\hline Genel Ort. & 69.2 & 0.882 & 14.3 & 47.1 & 30.2 & 40.7 & 30.6 \\
\hline$P<0.05$ & 0.000 & 0.000 & 0.000 & 0.000 & 0.163 & 0.000 & 0.000 \\
\hline$\%$ VK & 9.02 & 7.79 & 4.77 & 12.2 & 9.54 & 65.4 & 72.7 \\
\hline F hesap & $9.607 * *$ & $3.745^{* *}$ & $17.979 * *$ & $17.275^{* *}$ & 1.467 & $568 * *$ & $528 * *$ \\
\hline
\end{tabular}


Yalın çeşitler ve bu çeşitlerin çeşitli oranlarda birleştirilmesiyle oluşan karışımlar genetik bakımından yazlıktan kışlığa değişen karakterde çeşitler içerdiği için aralarında istatistiksel farkların önemli bulunması anlaşılabilir.

\section{Bazı değirmencilik ve hamur reolojik özellikleri}

Yaş gluten dışında ölçülen un randımanı, kül oranı, protein oranı, sedimantasyon ve enerji değerleri bakımından deneme konuları arasında istatistiksel önemde farklar tespit edilmiştir. Karışımların un randımanı yalın çeşitlerden yüksek, kül oranı ise düşük bulunmuştur. Sedimantasyon ve yaş gluten değeri bakımından yalın çeşitler karışımlardan daha üstün bulunmuştur. Ancak aradaki farklar istatistiksel olarak önemli bulunmamıştır (Çizelge 3).

Ekstensograf enerji değeri bakımından yalın çeşitler ve karışımlar arasında istatistiksel olarak önemli farklılıklar bulunmuştur (Çizelge 3). Karışım ve yalın çeşitlerin 45 . dakika ölçümlerindeki $F$ değeri $568^{* *}$, 90. dakikada ölçümlerin $\mathrm{F}$ değeri $528^{* *}$ olarak hesaplanmıştır. Karışım ve yalın çeşitlerden elde edilen hamurların ekstensoğraf enerji değerleri hamurun üretilmesinden 45 ve 90 dakika sonra belirlenmeye başlanmış ve $K_{2}, K_{5}$ ve Ç3 konularında ölçümler her iki ölçüm süresi içinde alınamamıştır. Karışımların ve yalın çeşitlerin 45 ve 90 dakika ölçümleri arasında farklılık olduğu ve 90. dakika ölçümlerinin 45. dakika ölçümlerinden daha düşük olduğu belirlenmiştir. Karışım ve çeşitlerin 45. ve 90. dakikadaki en yüksek enerji değerleri $\mathrm{K}_{6}$ (\% 30 Ceyhan $99+\% 30$ Sagittario + \% 10 Pehlivan + \% 10 Bezostaya + \% 20 Golia) ve $\mathrm{K}_{7}$ (\% 40 Golia + \% 30 Sagittario + \% 30 Odeskaya) konusundan elde edilirken, 45. ve 90. dakikadaki en düşük enerji değeri $K_{1}$ (\%50 Ceyhan $99+\% 50$ Sagittario) konusundan elde edilmiştir. Yalın çeşitlerden 45. dakikadaki en yüksek enerji değeri Ç 1 (Ceyhan 99) çeşidinden, 90. dakikadaki en yüksek enerji değeri Ç4 (Sagittario) çeşidinden elde edilirken, 45. dakikadaki en düşük enerji değeri Ç6 (Odeskaya) çeşidinden, 90. dakikadaki en düşük enerji değeri Ç6 (Odeskaya) ve $C_{15}$ (Golia) çeşitlerinden elde edilmiştir (Çizelge 3 ve Şekil 2).

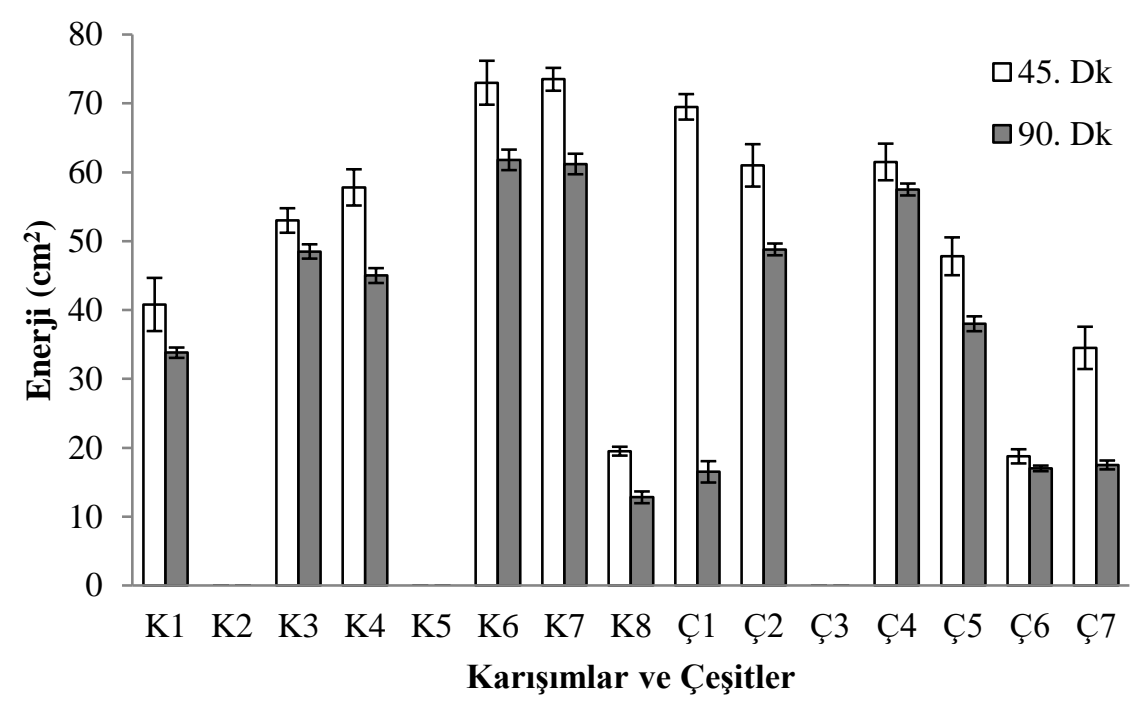

Şekil 2. Karışımlar ve yalın çeşitlerden hazırlanan hamurun enerji değerleri

Figure 2. Energy values of dough rheologica I properties of mixtures and pure varieties

Enerji değeri düşük olan hamurun hamur enerji değerleri ile benzerlik fermantasyona toleransının az olduğu göstermektedir. Hayta ve Çakmaklı (2001), farklı bilinmektedir (Dizlek ve ark., 2014). Çeşit buğday paçallarından elde edilen unların hamur karışımları ve yalın çeşitlerden elde edilen enerji değerlerinin $33.0-75.6 \mathrm{~cm}^{2}$ arasında unlardan yapılan hamurun enerji değerleri değiştiğini belirtmiştir. Benzer olarak, Aktaş ülkemizdeki yetiştirilen yerli ve yabancı orijinli $\quad$ (2012) Doğu ve Güney Doğu Anadolu Bölgesinde ekmeklik buğday çeşitlerinden elde edilen unların Diyarbakır, Malatya ve Mardin illerinde sulu ve 
kuru şartlarda yetiştirilen 15 ekmeklik buğday çeşitlerinden elde edilen unların hamur enerji değerlerinin 55,7 - $161 \mathrm{~cm}^{2}$ arasında değiştiğini belirtmiş ve en düşük hamur enerji değerine Osmaniyem çeşidinin, en yüksek hamur enerji değerlerine ise Dariel çeşidinin sahip olduğunu bildirmiştir. Dizlek ve ark. (2014) Çukurova Bölgesinde yetiştirilen 30 farklı ekmeklik buğday çeşidinden elde edilen unların hamur enerji değerlerinin 21,0 - $162 \mathrm{~cm}^{2}$ arasında değiştiğini belirtmiş, en düşük hamur enerji değerine $\mathrm{WL}$ 6718 çeşidinin, en yüksek hamur enerji değerine ise HP 1744 çeşidinin sahip olduğunu belirtmişlerdir

Verim ve bazı tarımsal özellikler arasındaki korelasyon

Tarla paçalları ile ekmeklik buğdayların kalitelerinin kontrolünü amaçlayan bu çalışmada her ne kadar elde edilen karışım buğdayların kaliteleri önemli olsa da tane verimi de ihmal edilmemelidir. Pearson korelasyon $(\mathrm{N}=60)$ analiz sonuçlarına göre; verim ile metre karedeki başak sayısı $\left(-0.486^{* *}\right)$, başakta başakcık sayısı ($\left.0.333^{* *}\right)$, olgunlaşma gün sayısı $\left(-0.351^{* *}\right)$, çıkış gün sayısı $\left(-0.334^{* *}\right)$, başakta tane ağırlığı ($\left.0.334^{* *}\right)$ ve bin tane ağırlığı $\left(-0.349^{* *}\right)$ arasında önemli $(P<0.01)$ negatif korelasyonlar elde edilirken, hektolitre ağırlığı ile $\left(0.359^{* *}\right)$ önemli pozitif korelasyonlar $(P<0.01)$ bulunmuştur.

\section{Karlılık analizi}

Yalın çeşitler ve karışımların Pazar değerleri arasında istatistiksel önemde farklar bulunmuştur. Yalın çeşitlerin ortalama Pazar fiyatı $0.910 \mathrm{TL} / \mathrm{kg}$ olurken karışımların ortalaması $0.919 \mathrm{TL} / \mathrm{kg}$ olmuştur. 3 numaralı yalın çeşit $0.940 \mathrm{TL} / \mathrm{kg}$ değeriyle en yüksek pazarlama değerine sahip çeşit olmuş bunu 5 numaralı karışım 0.936 TL /kg ile takip etmiştir.Pazarlama fiyatlarında alıcıların Macca ve Özberk'in (2012) işaret ettiği gibi görsel faktörlere dikkat ettikleri anlaşılmıştır.

Tane verimi bakımından deneme konuları arasında istatistiksel önemde farklar bulunmaktadır. Ceyhan-99 ve Adana-99, 742 ve 710 kg/da verim ile ilk iki sırada yer almışlardır. Ceyhan-99
Şanlıurfa'da sulanan koşullarda yüksek verimli çeşit olarak (Özkan,2016; Tanrıkulu, 2018) uzun yıllardır ekilmektedir. Ancak aynı çeşit Adıyaman ve Viranşehir bölgesinde ilave sulanan koşullarda en yaygın ekilen çeşitler arasında verim bakımından 4. Sırada (sırasıyla 406.7 ve 402.3 kg/da) yer almıştır ( Macca, 2016; Kanat,2017). Karışımların ortalama verimi $674 \mathrm{~kg} / \mathrm{da}$, yalın çeşitlerin ortalama verimi $684 \mathrm{~kg} / \mathrm{da}$ olarak bulunmuştur. İçinde Adana-99 un yer aldığı 4. Numaralı karışım 710 kg/da verim ile 3. Sırada yer almıştır. Pazarlama fiyatları bakımından Pehlivan çeşidi en yüksek pazarlama fiyatı verilen çeşit olurken (0.94 TL/kg), Adana-99 ve Pehlivan karışımı $0.936 \mathrm{TL} / \mathrm{kg}$ ile 2. Sırada yer almıştır. Ceyhan -99 ise $0.917 \mathrm{TL} / \mathrm{kg}$ ile alt sıralarda yer almıştır. Halbuki Viranşehir koşullarında Ceyhan$990.69 \mathrm{TL} / \mathrm{Kg}$ ile ilk sırada yer alırken, Pehlivan $0.65 \mathrm{TL} / \mathrm{kg}$ ile beş çeşit arasında sonuncu olmuştur (Kanat, 2017).Diyarbakır koşullarında ise yaygın ekilen 10 çeşit arasında sulanan koşullarda yetiştirilen Pehlivan $0.736 \mathrm{TL} / \mathrm{kg}$ ile 5.sırada yer alırken Ceyhan-99, $0.736 \mathrm{TL} / \mathrm{kg}$ ile 4. Sırada Sagittario $0.74 \mathrm{TL} / \mathrm{kg}$ ile 2. Sırada yer almıştır (Tanrıkulu, 2018).Yalın çeşitlerin ortalama pazar fiyatı (0.919 TL/kg) karışımların ortalamasından (0.910 TL/kg) yüksek bulunmuştur.

Dekara gelir değerleri bakımından karışımlar ve yalın çeşitler arasında istatistiksel olarak önemli $\left(F=431^{* *}\right.$ ) farklılıklar bulunmuştur (Çizelge 4).

Dekara gelir bakımından yalın çeşitler ve karışımlar arasında istatistiksel olarak önemli $\left(\mathrm{F}=431^{* *}\right)$ farklılıklar bulunmuştur (Çizelge 3). Karışımlarda dekara gelir en düşük $\mathrm{K}_{3} \quad$ (\%25 Ceyhan $99+\% 40$ Sagittario + \%15 Pehlivan + \% 20 Bezostaya) ve $\mathrm{K}_{8}$ (\%30 Adana $99+50$ Pehlivan + \% 20 Bezostaya) iken, en yüksek getiriye sahip olan konu ise $\mathrm{K}_{4}$ (\% 30 Adana $99+\% 50$ Sagittario + \% 20 Odeskaya) 'tür. Yalın çeşitlerin dekara gelirleri arasında en yüksek değere sahip olan

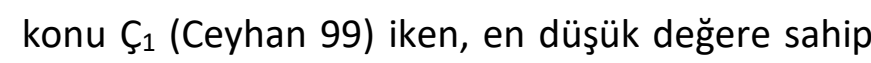
olan konu ise Ç5 (Bezostaja)'dir (Şekil 3). Karışımların ortalama dekara gelirleri $613 \mathrm{TL} / \mathrm{da}$ iken, yalın çeşitlerin ortalama dekara gelirleri $629 \mathrm{TL} / \mathrm{da}$ olarak bulunmuştur. Bu da bize yalın çeşitlerin dekara daha fazla gelir getirdiğini göstermektedir. 
Çizelge 4. Karışım ve yalın çeşitlerin Pazar fiyatları, verim ve dekara gelir ortalama değerleri ve oluşan gruplar Table 4. Means/grouping of marketing price, grain yield and net returns of mixtures and pure varieties

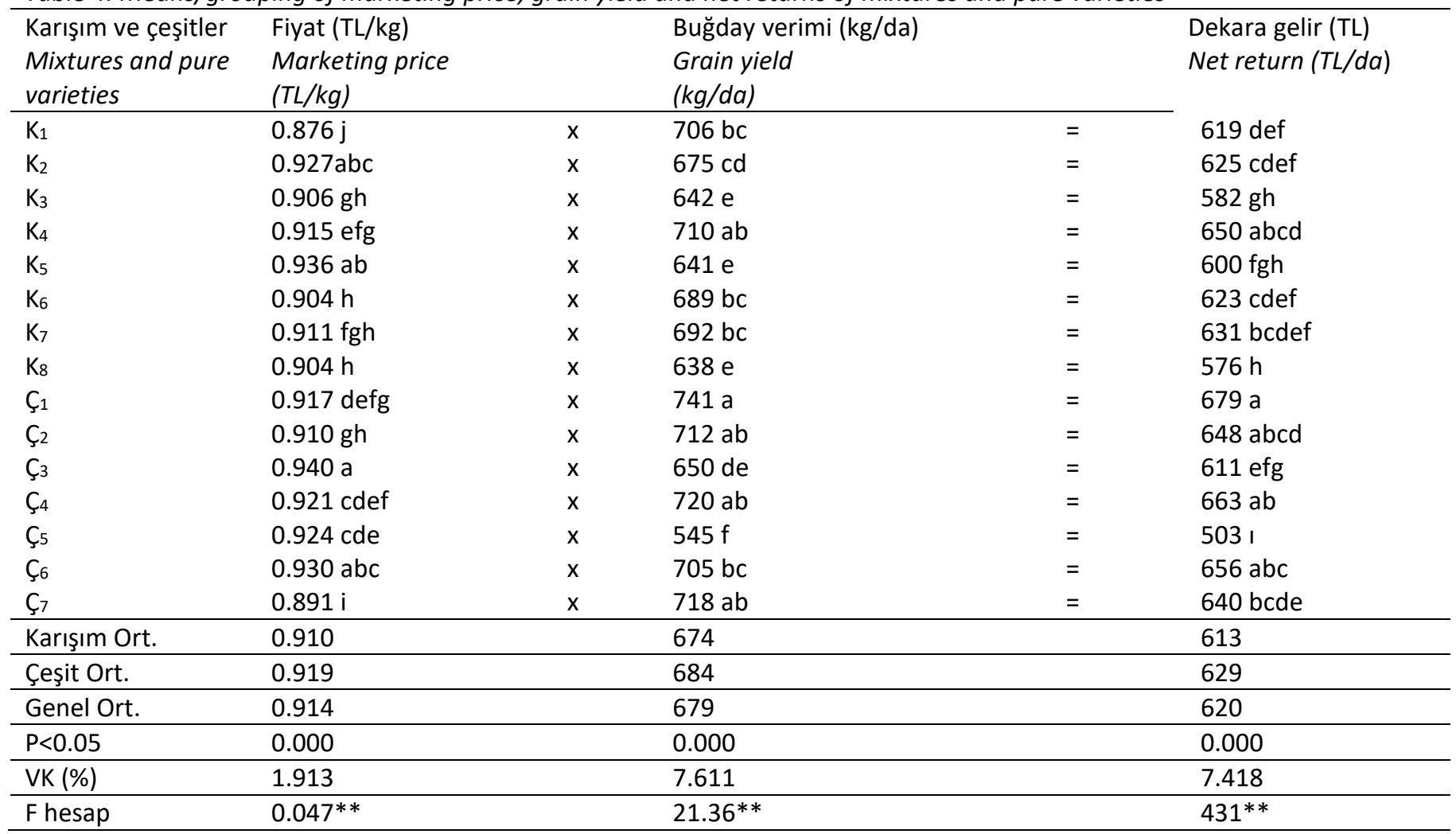

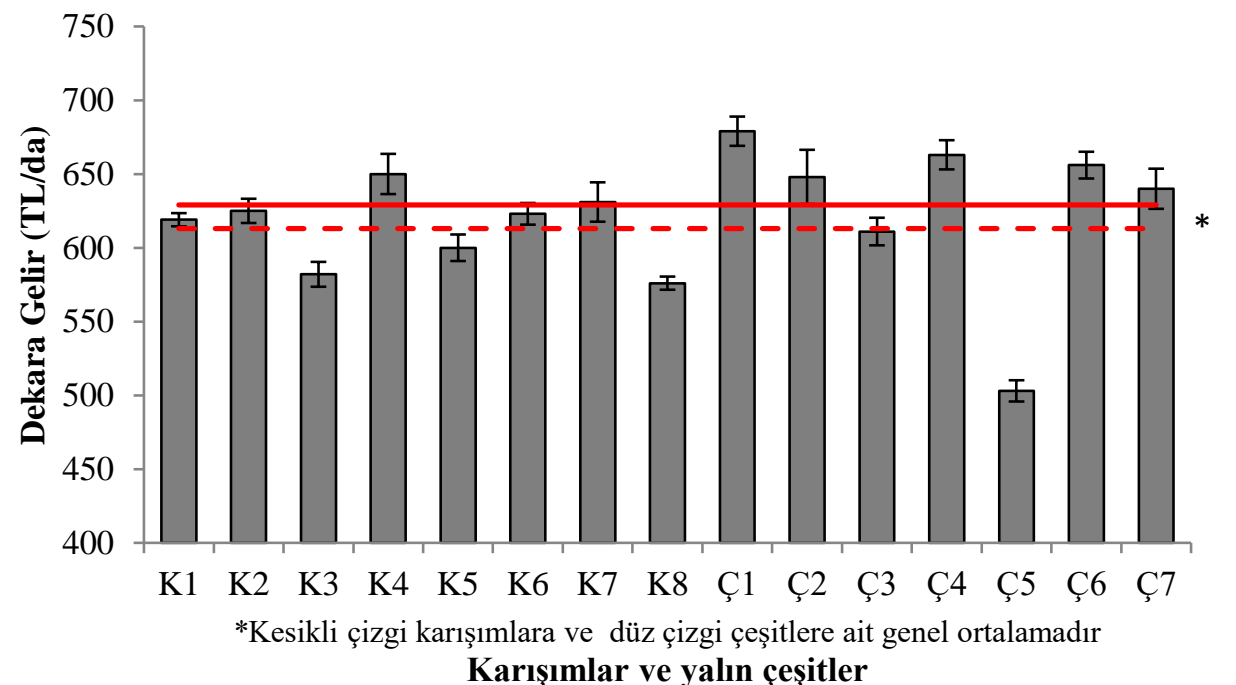

Şekil 3. Karışımlar ve yalın çeşitlere ait dekara gelir değerleri (TL/da)

Figure 3. Net returns (TL/da) for mixtures and pure varieties

Sonuç

Karışımlara ve yalın çeşitlere ait ortalamalar göz önünde bulundurulduğunda, karışımlarda gelir bakımından en yüksek değer $\mathrm{K}_{4}$ (\% 30 Adana $99+\% 50$ Sagittario + \% 20 Odeskaya) konusundan elde edilmiştir. Bu da $\mathrm{K}_{4}$ konusunun yalın çeşitler ile rekabet edebileceğini göstermiştir.

\section{Ekler}

Bu çalışma Mesude DiNÇ'in 'Diyarbakır bölgesi için ekmeklik buğday tarla paçallarının incelenmesi' isimli yüksek Lisans tezinden türetilmiştir.

\section{Kaynaklar}

Aktaş, H. (2012). Güneydoğu Anadolu Şartlarında Bazı Ekmeklik Buğday Çeşitlerinin Kalite Yönüyle Stabilite Yetenekleri ve Mikro Element İçeriklerinin 
Araştırılması. Doktora Tezi. Mustafa Kemal Üniversitesi Fen Bilimleri Enstitüsü, Hatay

Anonim, (2000). AACC Approved Methods of American Association for Cereal Chemistry, ICC Standard No:104-106.

Asghar, S, Kashif, M, Khan, A.S, Khaliq, I, Farooq, J.(2011). Comparative Studies on Some Yield Contributing Traits of Wheat Sown In Binary Mixtures. Frontiers of Agriculture In China, 5(2),141-145.

Cheema, N. M, Chowdhry, Y. M. A, Gliddon, C. J. (1988). Varietal Blends and Their Performance in Spring Wheat. Pakistan Journal of Agricultural Research 1988, 9(2), 141-146 Ref.29

Cox, C.M, Garrett, K.A, Bowden, R.L, Fritz, A.K, Dendy, S.P, Heer, W.F. (2004). Cultivar Mixtures For The Simultaneous Management of Multiple Diseases: Tan Spot and Leaf Rust of Wheat .The American Phytopathological Society 94(9), 961-969

Dai, J, Wiersma, J. J , Holen JR, D. L.( 2012). Performance of Hard Red Spring Wheat Cultivar Mixtures. American Journal of Agronomy, 104(1), 17-21

Dizlek, H, Gül, H, Özer, M.S, Aksoy, M, Özkan, H. (2014). Genetik Olarak İyileştirilerek Yetiştirilen 30 Farklı Ekmeklik Buğday Çeşidinin Değerlendirilmesi II. Reolojik ve Ekmek Özellikleri. Dünya Gıda Dergisi, 2014(7), 81-93.

Faraji, J. (2011). Wheat Cultivar Blends: A Step Forward to Sustainable Agriculture. Review. African Journal of Agricultural Research, 6(33),6780-6789.

Gallant, E. R, Dofings, S. M, Reisenauer, P. E, Donaltson, E. (2001). Diallel Analysis of Cultivar Mixtures in Winter Wheat. Crop Sci. 41,792-796.

Hayta, M, Çakmaklı, Ü.(2001). Optimization Of Wheat Blending to Produce Breadmaking Flour. Journal Of Food Process Engineering, 24, 179-192.

Jackson, L.F, Wennig, R.W. (1997). Use of Wheat Cultivar Blends to Improve Grain Yield and Quality And Reduce Disease and Lodging. Field Crops Research, 52(3), 261-269

Kaczmarek, S, Matysiak, K. (2017). Wheat Cultivars, Their Mixtures and Reduced Herbicide Doses as a Practical
Solution in Integrated Weed Management. Romanian Agrıcultural Research, 34, 1-8.

Kanat, Ş. (2017).Viranşehir'de Yetiştirilen Bazı Buğday Çeşitlerinin Verim, Kalite ve Pazar Fiyatı Yönünden Değerlendirilmesi. YL Tezi. HR.Ü.Fen Bil. Ens. Şanlıurfa.

Koçak, N, Seçkin, R, Atlı, A. (1993). Ekmeklik Buğday Paçalı Araştırmaları I. Paçal Uygulama İle Un Verimi Ve Kül Miktarının Düzeltilmesi. Gıda Dergisi. 18 (1), 13-19.

Macca,i.(2016). Adıyaman'da Ekilen Buğday Çeşitlerinin Tercihinde Verim, Kalite ve Pazar Fiyatının Etkisi. YL Tezi. HR.Ü.Fen Bil. Ens. Şanlıurfa

Macca, i, Özberk, i.(2012).Adıyaman Ürün Borsasında Ekmeklik Buğday Fiyatlarını Etkileyen Faktörler. Harran Gıda ve Tarım Bilimleri Dergisi,16(3),49-59.

Mille, B, Belhaj Fraj, M, Monod, H, DeVallavielle-Pope, C. (2006). Accessing Four Way Mixtures of Winter Wheat Cultivars From Performances of Their TwoWay and Individual Components. European Journal Of Plant Pathology, 114, 163-173.

Mundt, C.C, Schmitt, M.S. (1995). Choosing Crop Cultivars and Cultivar Mixtures under Low versus High Disease Pressure. A Case Study with Wheat. Crop Protection,14(6), 509-514

Özkan,R. (2016). Ekmeklik ve Makarnalık Buğdayda Azotlu Gübreye Tasarruflu Çeşitlerin Belirlenmesi. YL.Tezi. HR:Ü. Fen. Bil. Ens. Şanlıurfa

Smith, M.A.H, Wise, I.L, Fox, S.L, Vera, C.L, Dapauw, R.M, Lukow, O.M. (2014). Seed Damage And Sources of Yield Loss By Sitodiplosismosellana (Diptera: Cecidomyiidae) in Resistant Wheat Varietal Blends Relative to Susceptible Wheat Cultivars in Western Canada. The Canadian Entomologist, 146 (3), 335346.

Tanrıkulu,Ö.F. (2018). Diyarbakır'da Yaygın Olarak Yetiştirilen Ekmeklik ve Makarnalık Buğday Çeşitlerinde Verim, Kalite ve Karlılık. YL Tezi. HR.Ü.Fen.Bil. Ens. Şanlıurfa

Yurtsever,N.(1984). Deneysel İstatistik Metotlar. Köy Hiz. Gen. Müd. Yayınları, 1984, Ankara 